\title{
TRIM63 wt Allele
}

National Cancer Institute

\section{Source}

National Cancer Institute. TRIM63 wt Allele. NCI Thesaurus. Code C122759.

Human TRIM63 wild-type allele is located within 1p34-p33 and is approximately $17 \mathrm{~kb}$ in length. This allele, which encodes E3 ubiquitin-protein ligase TRIM63 protein, plays a role in the degradation of myosin proteins during amino acid starvation. 